Wilfrid Laurier University

Scholars Commons @ Laurier

$2-1-2005$

\title{
The Second Great Transformation: Human Rights Leapfrogging in the Era of Globalization
}

Rhoda E. Howard-Hassmann

Wilfrid Laurier University, hassmann@wlu.ca

Follow this and additional works at: https://scholars.wlu.ca/poli_faculty

\section{Recommended Citation}

Howard-Hassmann, Rhoda E., "The Second Great Transformation: Human Rights Leapfrogging in the Era of Globalization" (2005). Political Science Faculty Publications. 24.

https://scholars.wlu.ca/poli_faculty/24

This Article is brought to you for free and open access by the Political Science at Scholars Commons @ Laurier. It has been accepted for inclusion in Political Science Faculty Publications by an authorized administrator of Scholars Commons@ Laurier. For more information, please contact scholarscommons@wlu.ca. 


\title{
The Second Great Transformation: Human Rights Leapfrogging in the Era of Globalization
}

\author{
Rhoda E. Howard-Hassmann*
}

\begin{abstract}
Whether globalization improves or undermines human rights is not a matter that can be observed in the short term. Globalization is the second "great transtomation" spreading capitalism over the entire world. Many of its short-tem effects will be negative. Nevertheless, its medium and longterm effects may well be positive, as it impels social changes that will result in greater moves to democracy, economic redistribution, the rule of law, and promotion of civil and political rights. Capitalism is a necessary, though hardly sufficient condition for democracy: democracy is the best political system to protect human rights.

This does not mean that the non-Western world will follow the exact
\end{abstract}

\footnotetext{
* Rhoda E. Howard-Hassmann is Canada Research Chair in Global Studies and Political Science at Wilfrid Laurier University, and a Fellow of the Royal Society of Canada. Her books include Colonialism and Underdevelopment in Ghana (1978), Human Rights in Commonwealth Africa (1986), and Human Rights and the Search for Community (1995). She is also co-editor of An International Handbook of Human Rights (1987), and Sleeping under Bridges: Economic Rights in Canada and the United States (forthcoming, 2005). Her most recent volume, Compassionate Canadians: Civic Leaders Discuss Human Rights (2003) was named 2004 Outstanding Book by the Human Rights Section of the American Political Science Association. Her current research project is on the question of what the Western world owes Africa. Dr. Howard-Hassmann has been a Visiting Professor at four universities, and has presented invited lectures at many others. She is a member of six joumal editorial boards.

This paper derives from a talk the author gave at a conference on Globalization and the Human Condition, St. Thomas University, Fredericton, New Brunswick, Canada, I August 2001. She is grateful to the Social Sciences and Humanities Research Council of Canada for research funding, and to Anthony Lombardo and Dan Milisavljevic for research assistance. The author wrote several earlier dratts of this paper while James Farmer Visiting Professor of Human Rights at Mary Washington College in Fredericksburg, Virginia; she is most grateful to the College for the time it gave to her to devote to research. She is also grateful to the Canada Research Chairs program for the time she is able to dedicate to research.
} 
same path to protection of human rights that the Western world followed. No international law obliged the West to protect human rights during its own era of economic expansion. Thus, the West could practice slavery, expel surplus populations, and colonize other parts of the world. Genocide and ethnic cleaning were not prohibited.

\section{TABLE OF CONTENTS}

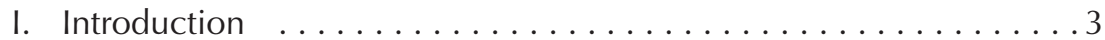

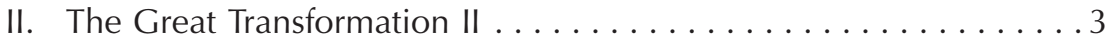

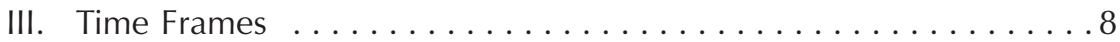

IV. Simple Models of the Relationship between Globalization and Human Rights ............... 14

A. Globalization and Human Rights: A Positive Relationship . . .14

B. Globalization and Human Rights: A Negative Relationship . . 16

V. Complex Models of the Relationship between Globalization and Human Rights . . . . . . . . . . . . . 19

A. The Optimistic Model . . . . . . . . . . . . . . . . . . 20

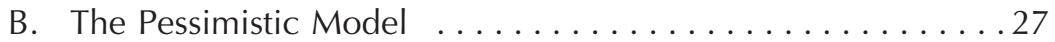

VI. Human Rights and Globalization ................ 31

A. Western Capitalist Evolution and the Absence of Human Rights Law . . . . . . . . . . . . . . . 31

B. Non-Western Capitalism and the

Presence of Human Rights . . . . . . . . . . . . . . . . . . 34

VII. Human Rights Leapfrogging $\ldots \ldots \ldots \ldots \ldots \ldots \ldots \ldots \ldots$

\section{Figures}

I (a) Globalization Causes Human Rights: A Simple Model . . . . . . . 14

I (b) Globalization Causes Human Rights:

The Simple Model Complicated . . . . . . . . . . . . . . . . . 14

I (c) Globalization Causes Human Rights:

The Simple Model Further Complicated ............. 15

II (a) Globalization Undermines Human Rights:

The Simple Model ......................... 16

II (b) Globalization Undermines Human Rights:

The Simple Model Complicated .................. 17

II (c) Globalization Undermines Human Rights:

The Simple Model Further Complicated .............. 18

III (a) The Second Great Transformation: An Optimistic Model . . . . . 21

III (b) The Second Great Transformation: A Pessimistic Model . . . . . 29

IV Social Action and Human Rights . . . . . . . . . . . . . 34 


\section{INTRODUCTION}

The non-Western world does not enjoy the advantage of human rights lawlessness. It does, however, enjoy other advantages occasioned by the presence of human rights. There is a global communications network and many global pro-human rights organizations. There is also the movement to global governance. Finally, and paradoxically, there is the global social movement against globalization, which forces some reflection upon its deleterious consequences.

Thus, the non-Western world benefits from geographical and chronological human rights "leapfrogging." This, along with the social changes that global capitalism and industrialism may impel, may mean that the medium and long-term consequences of globalization are positive for human rights.

\section{THE GREAT TRANSFORMATION II}

Globalization is changing the conditions under which all countries and societies are integrated into world politics and the world economy. Among human rights activists and some human rights scholars, there is a debate about whether globalization is "good" or "bad" for human rights. Peter Schwab and Adamantia Pollis, for example, focus only on the negative aspects of globalization, stating "Clearly globalization has had a deleterious effect on the entire complex of human rights . ..."1 I suggest that this is a false debate. The issue is not whether globalization is a "thing" out of control, eating up traditional societies, local values, and local economies. This is inevitable. Globalization cannot be stopped, and its forces will undermine what is left of purely local societies. The issue is the kinds of changes that globalization is likely to effect in the long as well as in the medium and short terms, and how societies and individuals will react to those changes. To argue whether globalization as a process is "good" or "bad" is as irrelevant as arguing whether the transition from an agrarian to an industrial society in the Western world from the eighteenth to the twentieth century was good or bad. Many complex social changes occurred: some economies were strengthened, some were weakened. Some states rose, some fell. Some social classes and categories benefitted, others sank into oblivion.

Globalization is not only inevitable; it is, despite all its costs, the only path to long-term growth. As Amartya Sen has stated, "The one solution [to

1. Peter Schwab \& Adamantia Pollis, Globalization's Impact on Human Rights, in Human Rights: New Perspectives, New Realties 209, 217 (Adamantia Pollis \& Peter Schwab eds., 2000). 
the problems caused by globalization] that is not available is that of stopping globalization of trade and economies." 2 "The countries that change the least," notes The Economist, "where the costs of growth are closest to zero, are those where poverty and disease are worst." ${ }^{\prime 3}$ But there are, nevertheless, many and severe short-term costs on the path to medium or long-term growth. One solution that may partially alleviate the problems caused by globalization is the "leapfrogging" of human rights across time and space, as discussed below. The global human rights regime and the global human rights process can perhaps remedy some of the dangers of the global economic system.

Undoubtedly, however, the process of globalization is causing human rights abuses in the short term, some of them very severe. ${ }^{4}$ Before presenting my argument, therefore, I wish to make clear my personal position on the human rights abuses caused by globalization. I believe that in the short as well as the medium and long terms every effort ought to be made to ensure that everyone enjoys her or his full range of human rights, including economic rights. I do not believe that present generations should be told that they must suffer, for the sake of future generations. More pragmatically, I would like to see a world in which every policy change meant to promote globalization was obliged to adhere to the principle that the poorest not be rendered even worse off. This would require that states, international organizations and multinational and national corporations submit all policies that promote globalization to a "human rights filter" that especially focuses on economic rights. ${ }^{5}$ Therefore, I fully support all efforts to protect individuals from human rights abuses consequent on globalization. I am particularly concerned that the pace of change be controlled and "shock treatments" not be imposed by international institutions on societies not able to absorb the shock. As Sen argues, "In the context of economic disparities, the appropriate response has to include concerted efforts to make the form of globalization less destructive of employment and

2. Amartya Sen, Development as Freedom 240 (1999).

3. Face Value: Why Naomi Klein Needs to Grow Up, Economist, 9 Nov. 2002, at 70.

4. See Robert McCorquodale \& Richard Fairbrother, Globalization and Human Rights, 21 Hum. Rts. Q. 735, 742-50 (1999). See also The Realization of Economic, Social and Cultural Rights: Globalization and its Impact on the Full Enjoyment of Human Rights, Preliminary Report submitted by J. Oloka-Onyango \& Deepika Udagama, in accordance with Sub-Commission resolution 1999/8, U.N. ESCOR, Sub-Comm'n. on the Promotion and Protection of Hum. Rts., 52d Sess., Agenda Item 4, E/CN.4/Sub.2/2000/ 13 (2000).

5. For example, such a "filter" is part of the mandate of the Inspection Panel, which considers the environmental impact of World Bank projects. See Jonathan Fox, Transnational Civil Society Campaigns and the World Bank Inspection Panel, in Globalization and Human Rights 171, 177 (Alison Brysk ed., 2002). 
traditional livelihood, and to achieve gradual transition." ${ }^{6}$ The following analysis is meant to address the possible long-range human rights outcome of globalization, not to suggest in any way that legal activists, members of civil society, and others who point out its human rights abuses in the short term should cease their activities. On the other hand, the following analysis is meant to persuade readers that in the long run, globalization may well create a world of increased prosperity, democracy, and protection of human rights.

Karl Polanyi wrote The Great Transformation to explain the economic, social, and political changes that occurred in Europe, particularly Britain, from the end of the eighteenth century to the Second World War.? This was a period of about 160 years, known to have radically transformed the way people lived. Peasants became artisans, industrialists, members of the proletariat: they migrated from villages to cities; they moved from closed, church-based societies to open, secular communities. Most important to Polanyi was the newness of a society based only on gain, and the very rapid end of the "social," in which previously mankind had always been embedded. Market relations took over from the relations of reciprocity and redistribution which had previously regulated social life. Land had been the basis not only of peasants' economic security but also of their feeling of connection to the places and communities of their birth. It now became a commodity to be used by landlords as they saw fit, even if such use meant expulsion of the peasants. A society in which all members had relations of obligation and reciprocity to all others gave way to one in which individuals in their different roles were cut off from each other, and related to each other only within the marketplace. ${ }^{8}$

What is happening now is the second great transformation. Globalization is the final assault of capitalism on all those areas of the globe that previously escaped it, either because of explicit communist or socialist politics, because of national policies of protectionism or withdrawal from the world economy, or because capitalism had no interest in the region as a source of capital or resources, a source of workers, or a market. All over what was formally the noncapitalist, or only partly capitalist worlds-what Immanuel Wallerstein called the peripheral and semi-peripheral parts of the world ${ }^{9}$ - the social is giving way to the profit motive, as it did in Western

6. Sen, supra note 2, at 240. On shock treatments, see also Joseph E. Stiglitz, Globalization AND ITS DisCONTENTS (2002).

7. See Karl Polanyi, The Great Transformation: The Political and Economic Origins of Our Time (1944).

8. See Emile Durkheim, The Division of Labor in Society (1933).

9. Immanuel Wallerstein, The Modern World-System: Capitalist Agriculture and the Origins of the European World-Economy in the Sixteenth Century 199-225 (1974). 
Europe two centuries ago. Those with power over ordinary people no longer feel any sense of obligation to them. As Zygmunt Bauman puts it, the multinational corporations that are symbols of globalization are the new absentee landlords, foreign investors without obligation to their local employees or their local suppliers, and certainly without obligations to the local communities in which they make investments. ${ }^{10}$ There is, he says, a "disconnection of power from obligations": the investors enjoy "freedom from the duty to contribute to daily life and the perpetuation of the community." ${ }^{11}$ In former times in the West and in local, peasant, preindustrial societies elsewhere during the present era, landlords and notables sometimes ensured that minimum economic security was provided for all, by controlling distribution of land and by storing food in anticipation of shortages. This security is now long gone. Likewise, in the former Communist world, policies that protected the minimum needs of "the people" to housing, food, and health-care are giving way to policies that deny economic rights. ${ }^{12}$ These policies make economic security dependent on individuals' and families' capacities to find scarce employment, obtain insecure property rights, or invest in erratic and incalculable international capital markets. In much of the former "Third World" the social-as characterized by kin-based village societies and by personalized kadi-based systems of justice-is also giving way to urbanization and the rules of authoritarian bureaucracies. ${ }^{13}$ The protections of belonging, however materially poor the community to which you belong, are giving way to urban anomie, the feeling that no one cares, no one is there to help, no one knows who you are. The place of one's origin-both the physical location and one's place in the status hierarchy-is no longer the place where one can rely on communal assistance. In the former "second" (communist) and "third" worlds, billions of people are experiencing what Polanyi called an "avalanche of social dislocation." 14

10. Zygmunt Bauman, Globalization: the Human Consequences 9 (1998).

11. Id.

12. Protection of these economic rights was, however, always dependent on political conformity and the capacity to escape the auto-genocidal policies of communist dictatorships. On the 100 million people killed by their own governments in the Soviet Union, China, and other communist countries, see Stephane Courtols et al., The Black Book of Communism: Crimes, Terror, Repression 4 (Mark Kramer ed., Jonathan Murphy \& Mark Kramer trans., 1999). Moreover, in the Soviet Union housing and health care were very poor quality. See Nick Eberstadt, The Poverty of Communism (1988).

13. Max Weber used the term "kadi" to describe informal systems of justice in which individuals approached local notables for assistance and justice. Max Weber, Bureaucracy, in From Max Weber: Essays in Sociology 196, 219-21 (H.H. Gerth \& C. Wright Mills eds. \& trans., 1946). This type of justice persists in countries such as Saudi Arabia and Afghanistan, in which princes or warlords periodically make themselves available to ordinary people who are experiencing difficulties.

14. Polanyı, supra note 7 , at 40 . 
Globalization is defined by Malcolm Waters as "[a] social process in which the constraints of geography on social and cultural arrangements recede and in which people become increasingly aware that they are receding." ${ }^{\prime 15}$ In agreement with Waters, Bauman argues that the present era is, in effect, the "end of geography."16 Held, McGrew, and their colleagues offer a similar definition: globalization is "a process (or set of processes) that embodies a transformation in the spatial organization of social relations and transactions, generating transcontinental or interregional flows and networks of activity, interaction, and power."17 These authors are correct to draw attention to social and cultural arrangements. The information explosion, the world-wide reach of mass media, and ease of communications certainly do affect cultures. Similarly, ease of travel, migration, and circulation among ancestral and new homes change social arrangements. Nevertheless, the chief impetus and beneficiary of globalization is capitalism. Capitalist production is expanding throughout the world: as Michael Hardt puts it, "capital in some sense mediates all forms of production."18 Capitalism is the economic system behind new technologies of information and communication, behind unprecedentedly large and quick capital flows, and behind the capacity of transnational corporations to spread all over the world. George Soros makes this point in his own definition of globalization as "the free movement of capital and the increasing domination of national economies by global financial markets and multinational corporations. ${ }^{19}$ In 1997 Jeffrey Sachs pointed out that whereas twenty years earlier, only about 20 percent of the world's population had been living under capitalism (the rest living either under command socialism or in countries attempting to combine capitalism and socialism), by the time he wrote the percentage had increased to $90 .{ }^{20}$ As societies hitherto outside the capitalist fold adopt a capitalist mode of production, many social changes occur.

Anthony Giddens quotes Archbishop Wulfstan, who in a sermon in the English city of York in 1014 said "The world is in a rush, and is getting close to its end." ${ }^{21}$ This is the reaction of many people to the current era: as

15. Malcolm Waters, Globalization 3 (1995).

16. Bauman, supra note 10 , at 12 .

17. David Held \& Anthony McGrew, with David Goldblatt \& Jonathan Perraton, Globalization, 5 Global Governance 483, 483 (1999).

18. Michael Hardt, Globalization and Democracy, Institute on Globalization and the Human Condition, McMaster University, Hamilton, Ontario, Canada, Working Paper Series, GHC 01/1, 2 (2001), available at www.humanities.mcmaster.ca/ global/wps/ hardtfinal.PDF.

19. George Soros, George Soros on Globalization 1 (2002), quoting Jedediah Purdy, The Values of the Market: Stiglitz and Soros, 16 ETHICS \& INT'L Aff. 143, 143 (2002).

20. Jeffrey Sachs, New Members Please Apply, TIme, 7 July 1997, at 11-12, cited in RicharD Falk, Predatory Globalization: A Critique 141 (1999).

21. Anthony Giddens, Runaway World: How Globalization is Reshaping Our Lives 1 (2003). 
Bauman puts it, globalization is a sense of "things getting out of hand."22 Integration of the "rest" of the world-Asia, Africa, and Central and Latin America-into the global economy has been occurring at least since WWII, and has been dramatically speeded up by globalization. Russia and the exSoviet "transitional" societies are also now being integrated into the world economy, several decades later than would have happened had they moved from peasant to capitalist modes of production in the early twentieth century. The leaders of China in 1979 decided to adopt a controlled capitalism. All these societies want to catch up for lost time. They hope that by joining the world capitalist economy, their own standards of living and political and social arrangements will improve.

These manifold changes impel a human rights debate. Will globalization improve or undermine individuals' access to economic benefits? Will it improve or undermine the state of civil and political rights? There is no necessary connection between globalization and improved conditions, nor between globalization and deteriorating conditions. To understand the second Great Transformation, we must look at the interactions among economic and social change, political organization, and social movements.

\section{TIME FRAMES}

Investments by transnational corporations are frequently used in the political debate as a proxy for globalization. Thus, McCorquodale and Fairbrother argue that "The apparent universal market and demand for a product which is . . . produced by a transnational corporation, could be seen as a manifestation of new opportunities provided by globalization," but they then caution that "the impacts of the universal market . . . could indicate the dangers in this process of globalization."23 Opponents to globalization realize that the world-wide integration of the economic system is its defining characteristic.

In 1996 and 1999, Human Rights Quarterly published a debate about the relationship between globalization and human rights. The relevant variables in this debate were foreign investment by multinational corporations (representing globalization) and civil and political rights (representing human rights). William $\mathrm{H}$. Meyer investigated two contrasting theses. ${ }^{24}$ The

\footnotetext{
22. BAUMAN, supra note 10 , at 59 .

23. McCorquodale \& Fairbrother, supra note 4, at 735.

24. See William H. Meyer, Human Rights and MNCs: Theory Versus Quantitative Analysis, 18 Hum. RTs. Q. 368 (1996); see also Stephen Hymer, The Multinational Corporation and the Law of Uneven Development, in Introduction to the Sociology of "Developing Societies" 128 (Hamza Alavi \& Teodor Shanin eds., 1982).
} 
first thesis, as exemplified by the early work of Daniel Lerner, was that multinational investment is an "engine of development." 25 It promotes economic rights through investment and job creation, and civil and political rights through the creation of a stable and tolerant environment. The second thesis was that multinational investment causes underdevelopment. Meyer referred to this proposition as the Stephen Hymer thesis. The "Hymer thesis" refers to an article that was very influential among adherents of the Marxist and dependency schools of thought in the 1970s. Hymer argued that foreign investment undermines national development and-by extrapolationsubsequent improvements in human rights. ${ }^{26}$ Meyer used quantitative data about fifty-two countries in 1985 and twenty-nine countries in 1990 to investigate the relationship between TNC investment and human rights, assuming "a time lag of roughly two to three years between the determinants and the level of human rights." ${ }^{27}$ He compared levels of direct US foreign investment and foreign aid to levels of civil liberties and political rights in recipient countries, as ranked by Freedom House, and to quality of life indicators, namely the adult illiteracy rate, the infant mortality rate, and life expectancy at age one. Over this very short time period, he argued, there was an improvement in human rights in countries receiving significant foreign investment. "[T] he presence of multinational corporations . . . [was] positively associated with political rights and civil liberties as well as with economic and social rights in the third world." ${ }^{28}$ This, he said, confirmed the thesis that multinational investment was an engine of development. ${ }^{29} \mathrm{He}$ did not, however, propose why this might have occurred. Nor did Meyer attempt an explanation in a later volume. He noted only "We need to be clear on the good done by MNCs, as well as the bad . . ." "130

Meyer very generously gave a colleague, Jackie Smith, access to his data. She then re-analyzed it, comparing it with her own study. Rather than rely on data about civil and political liberties from Freedom House, which some critics consider to be biased against communist countries, Smith chose data from Amnesty International and the US State Department. She also used World Bank data on direct foreign investment from all countries, not only from the United States. Smith found that foreign investment did not promote civil and political rights. Rather, Smith concluded that there was "little relationship between DFI [direct foreign investment] and political and

25. See Daniel Lerner, The Passing of Traditional Society: Modernizing the Middle East (1958).

26. See Hymer, supra note 24.

27. Meyer, supra note 24 , at 390 .

28. Id. at 368 .

29. Id. at 397 .

30. William H. Meyer, Human Rights and International Political Economy in Third World Nations: Multinational Corporations, Foreign Aid, and Repression 213 (1998). 
civil rights practices. ... The factors that seem to have a much stronger and consistent impact on a government's human rights practices relate to more general structural factors, namely GNP per capita and levels of public debt." ${ }^{\prime 31}$ In response, Meyer argued that different data could generate different results and that "at the level of aggregate cross-national studies, the empirical evidence linking MNCs [multinational corporations] to human rights is mixed." ${ }^{32}$ Moreover, he noted, the aggregate level of analysis implied by statistical correlations simply could not be transferred to the level of analysis of the individual case: Smith and her colleagues had referred to several cases, such as investment by Shell Oil in Nigeria's Ogoniland, to point out the intuitive unreliability of Meyer's original thesis. $^{33}$

In this debate, Meyer and Smith both relied on the assumption that a relationship between globalization and human rights could be determined by data spanning a very few years. Without implying disrespect for the important and instructive quantitative evidence generated by these scholars, I want to argue that the ultimate relationship between globalization and human rights cannot be predicted over such a short time span. The first Great Transformation lasted about 200 years. The ancestors of Westerners who presently live in comparative prosperity suffered many a bumpy road between their peasant past and their urban present, even among those who were fortunate enough never to know along the way war, genocide, or other such drastic misfortunes. The consequences for human rights of enormous social upheaval cannot be determined in the short run.

Better, then, to look to the medium to long term to try to ascertain the effects of globalization on human rights. The long term is too long for adequate academic prediction; it is a century or two into the future. The medium term might be more reachable. It permits us to look back to the more recent past to analyze social, political, and economic changes that have occurred as a result of what we now call globalization. South Korea provides a model of almost complete transition from a peasant to an urban society, from a dictatorship to a democracy, over a period of fifty years. ${ }^{34}$ China shows the very rapid transition from a collectivist, command economy to an individualist, entrepreneurial economy within the space of twenty years (since the turn to regulated capitalism in 1979), yet with a

31. Jackie Smith, Melissa Bolyard \& Anna Ippolito, Human Rights and the Global Economy: A Response to Meyer, 21 Hum. Ris. Q. 207, 218 (1999).

32. William H. Meyer, Confirming, Infirming, and "Falsifying" Theories of Human Rights: Reflections on Smith, Bolyard, and Ippolito through the Lens of Lakatos, 21 Hum. RTs. Q. 207, 222 (1999).

33. Smith et al., supra note 31 , at 208.

34. For an analysis of the South Korean case, see Jack Donnelly, Universal Human Rights in Theory and Practice 170-78 (1989). 
party-bureaucratic dictatorship still in place. In former Eastern Europe and the Russian Empire, there are multiple examples of greater and lesser success in integrating into the world capitalist system and in adopting democracy since 1989.

Democracy here stands as a substitute for human rights. Both Jack Donnelly and Michael Freeman have warned that political democracy does not necessarily imply protection of human rights. ${ }^{35}$ Democratic rule can result in majoritarian rule, undermining the rights of minorities or of racially distinct groups, as in the all-white "democracy" of South Africa during the apartheid era or as in Israel at present. Majoritarian democracy can also undermine the rights of women, as in a Bahamian referendum in 2002 in which voters decided against granting children born of Bahamian mothers and foreign fathers the same citizenship rights as children born of Bahamian fathers and foreign mothers. ${ }^{36}$ Nevertheless, modern democratic states buttressed by the rule of law and by a civic culture of activism and political freedom are more likely than any other type of political system to protect human rights. And this is precisely the point. Democratic principles of government, the rule of law, and a civic culture took centuries to emerge in Western Europe and North America, with intervening episodes of dictatorship and fascism. Until well into the twentieth century, what are now known as human rights were systematically denied to the vast majority of Westerners. Rights-based liberal democratic societies certainly did not emerge through some easy, predictable, and inevitable coincidence of capitalism and rights.

A perfectly detached social scientist might argue that there is no need to look to either the short or the medium term to ascertain the relationship between globalization and human rights. The eventual outcome of the Industrial Revolution could certainly not have been predicted in Europe in 1780: so too the outcome of globalization cannot be predicted anywhere in the world in the early twenty-first century. But such a social scientist would not have taken account of globalization's capacity to "speed up the world."37 Economic policies change quickly with international institutions such as the World Bank to guide the changes and foreign consultants available to teach the rules and practices of capitalism to willing policy makers and entrepreneurs. ${ }^{38}$ Political changes are guided by constitutional

35. See Jack Donnelly, Human Rights, Democracy, and Development, 21 Hum. Rts. Q. 608 (1999), See also Michael Freeman, The Perils of Democratization: Nationalism, Markets and Human Rights, 2 Hum. Rts. Rev. 33 (2000).

36. CNN.com, World Electionwatch, The Bahamas, 27 Feb. 2002, available at www.cnn. com/WORLD/election.watch/americas/bahamas.html.

37. Held \& McGrew, supra note 17 , at 484 .

38. The disastrous "shock treatment" transformation of the Soviet Union from communism to Mafia-style capitalism was a consequence of advice both from the international 
and legal consultants. Social changes are influenced by international and transnational social movements, which strive to protect and promote human rights at the very time that powerful political and economic forces undermine them.

Assuming that the rest of the world may someday be in the same fortunate position as the West, enjoying a relatively rights-protective society, it may not be necessary to wait 150 or 200 years to achieve such a happy state. Medium term analysis does seem possible. Perhaps some of the more economically successful post-Communist countries, such as Hungary or Poland, will soon provide evidence of "short" medium-term change, of fifteen or twenty years. Certainly, in the period of extremely rapid communications, capital transfers, and even transfers of material goods, the medium term may turn out to be much shorter than in the past.

Even so, it is unwise to think that the benefits of democracy, the rule of law, and a human rights culture will normally be reaped in the short or medium term. In most societies entering the world capitalist economy, there will be severe social disruption and much exploitation of (newly available) labor, including, but by no means confined to, female and child labor. In the 1980s, the wages of young women workers in the export-processing zones of Asia and Latin America were frequently so low that they did not earn enough to meet their basic needs. ${ }^{39}$ Nor will such a phenomenon be confined to "Western" or "Northern" exploitation of the "non-Western" or "Southern" worlds. Capitalists from the former "Third World" are as capable as were the early English industrialists of exploiting their own workers, even to the point of severe personal injury. In some Asian-owned factories in China in the 1990s, workers were subject to corporal punishments and often suffered industrial amputations because of nonexistent health and safety regulations; Taiwanese, Hong Kong, and South Korean capitalists conspired with the Party-state against Chinese workers. ${ }^{40}$ Mexican entrepreneurs take advantage of their proximity to the United States to employ women workers in severely abusive conditions, prying into the most personal biological details of the women's lives to extract the maximum amount of profit. ${ }^{41}$ States and TNCs often collude in denying rights to their citizens.

financial organizations and from independent—and quite entrepreneurial—consultants. See Stiglitz, supra note 6, at 138 .

39. Export Processing Zones in Five Countries: The Economic and Human Consequences, Asia Partnership for Human Development 76-122 (Dennis Shoesmith ed., 1986).

40. Anita Chan, Labor Standards and Human Rights: Chinese Workers under Market Socialism, 20 Hum. RTs. Q. 886, 893-97 (1998).

41. Kathryn Kopinak, Gender as a Vehicle for the Subordination of Women Maquiladora Workers in Mexico, 22 Latin American Perspectives 30, 30 (1995). 
In this respect, Donnelly's injunction to scholars to view states as protectors of the human rights of their citizens in the new globalized world, rather than as violators of their citizens' rights, seems slightly idealistic. ${ }^{42}$ It is true, as Beetham puts it in agreement with Donnelly, that "nation-states remain for the foreseeable future the necessary instruments for the provision of security and welfare for their citizens." ${ }^{43}$ Although sovereignty may be eroding as nations sign on to international agreements, international bodies possess no enforcement powers when it comes to human rights. Nevertheless, whether their powers derive from local or from global political and economic relations, nondemocratic states are run by elites who act in their own interests. They are no more likely to protect their citizens' interests against foreign exploiters than they were to protect them against local exploiters. Thus also, the recent, romantic stress on the "local" as "the radical other" opposed to the "global" is far-fetched. ${ }^{44}$ Without (international) standards and practices of human rights, the autonomy of the local does not protect human rights; it merely protects local elites.

Whether for good or ill in human rights terms, social relations will change in the new global society. Societies will become more fluid; individuals will be more mobile, social norms will change, and traditional roles will give way to new ideas of how to behave. There will be new relations between the sexes. Persons formerly holding authority will find they are unheeded, while hitherto disreputable individuals will gain credence as role models in a new entrepreneurial world. Guns and drugs will be considered as legitimate objects of exchange, much as they were during the great European expansionist period of colonization. Some people will be confused by these changes and long for a simpler time with a stricter normative order. Among them, some will-and do-fight viciously to retain the older world from which they are being so abruptly torn. In such situations of flux, there will be no necessary short or medium-term correlation between the processes of globalization and the entrenchment of human rights, either positive or negative. Nor will there necessarily be such connection in the long term. As is shown below, no simple model of correlations can predict the human rights future.

42. See Jack Donnelly, Human Rights, Globalization and the State, in The Role of the NationState in the 21st Century: Human Rights, International Organisations and Foreign Policy (Essays in Honour of Peter Baehr) 401 (Monique Castermans-Holleman, Fried Van Hoof \& Jacqueline Smith eds., 1998).

43. David Beetham, Human Rights as a Model for Cosmopolitan Democracy, in Re-ImAGINING Political Community: Studies in Cosmopolitan Democracy 58, 65 (Daniele Archibugi, David Held \& Martin Kohler eds., 1998).

44. Arif Dirlik, Place-Based Imagination: Globalism and the Politics of Place, in PLACES AND Politics in an Age of Globalization 15, 15 (R. Prazniak \& Arif Dirlik eds., 2001). 


\section{SIMPLE MODELS OF THE RELATIONSHIP BETWEEN GLOBALIZATION AND HUMAN RIGHTS}

Both proponents and opponents of globalization appear to rely on relatively simple models of the relationship between the two.

\section{A. Globalization and Human Rights: A Positive Relationship}

A simple model of a positive relationship between globalization and human rights seems to posit the following inevitable relationship.

FIGURE I (a)

Globalization Causes Human Rights: A Simple Model

globalization $\Rightarrow$ human rights

This relationship seems to be what much of the positive rhetoric around globalization refers to. Nothing has to be done by social actors to promote human rights in societies experiencing globalization: human rights will "emerge," as it were, as societies globalize. In his time, Polanyi referred to a similar "utopian endeavor of economic liberalism to set up a selfregulating market system," in the belief that a free, self-regulated market would necessarily result in liberal democracy and peace. ${ }^{45}$ This is a nonacademic rhetoric, positing that simple contact among societies will result in a merging of social values, without specifying what kind of contact, among which social actors, can result in such positive, rights-inducing changes. There was and is, however, an underlying belief that wealthier societies are necessarily more likely to protect human rights than poorer societies.

FIGURE I (b)

Globalization Causes Human Rights: The Simple Model Complicated

globalization $\Rightarrow$ wealth $\Rightarrow$ human rights

The thesis that globalization causes human rights via increased wealth resembles the "engines of development" model discussed by Meyer. ${ }^{46}$

45. POLANYI, supra note 7 at 29.

46. See Meyer, supra note 24, at 391-97. 
Globalization develops an economy: that is, it increases its wealth. Wealthier societies are more likely to protect human rights than poorer societies. This is also the model about which Meyer and Smith et al. debated, using TNC or MNC investment as a proxy for globalization. ${ }^{47}$

A version of this model is the notion of "trickle-down" wealth creation: whatever the short-term costs to the poor, in the medium term the wealth accrued by the rich will trickle down to them. But during the early stages of urbanization and industrialization in the first Great Transformation in Western Europe, wealth did not trickle down in a steady fashion. Thus, in Britain, the Speenhamland laws were introduced in the late eighteenth century to provide minimum sustenance to the new poor. ${ }^{48}$ But in 1834, the Speenhamland Laws were abolished. ${ }^{49}$ The new poor did not overcome their miserable situation until they achieved, first, the universal male franchise and then the right to form trade unions. The period 1834-1895 was one of horrific poverty in the midst of great wealth, the kind of poverty that preoccupied Marx and Engels and persuaded them of the need for working men's associations, if not socialist revolution. ${ }^{50}$ Minimum welfare provisions-what we now call economic rights-were not widespread in Britain until after the Second World War. This suggests the need for a model of the relationship between globalization and human rights that takes account of political variables.

FIGURE I (c)

Globalization Causes Human Rights: The Simple Model Further Complicated

globalization $\Rightarrow$ markets $\Rightarrow$ liberal economic order $\Rightarrow$ democracy $\Rightarrow$ human rights

A yet more complicated version of the optimistic logic about the relationship between globalization and human rights specifies the intervening variables between wealth and human rights. Globalization opens up markets; markets are the basis of the liberal economic order; the liberal economic order is the basis of democracy; democracy is the basis of human rights. Again, however, there is no necessary causation here. Markets can result in a liberal economic order-or, as proponents of global trade suggest, a liberal economic order can open up markets. But to enforce their populations' acceptance of these markets, states can and do impose

47. $I d$.

48. Id. at 77-85.

49. See generally Fred Block \& Margaret Somers, In the Shadow of Speenhamland: Social Policy and the Old Poor Law, 3 Politics \& Society 283 (2003).

50. See Frederick Engels, The Condition of the Working Class in England (Panther, 1972). See also Karl Marx \& Friedrich Engels, The Communist Manifesto (Penguin, 1967). 
authoritarian rule. Populations used to having their own internal markets protected can erupt easily in rebellion when their local markets are taken over by foreign produce, leaving many local producers unemployed. State elites who profit from those new markets-or who, against their better judgment, are forced to acquiesce to outside market pressures-may well respond with force.

\section{B. Globalization and Human Rights: A Negative Relationship}

It is because of the complicated and highly political nature of the relationship between globalization and human rights that the anti-globalization social movement has emerged. The anti-globalization movement posits an opposite model of the relationship between globalization and human rights. In simplest terms, it is axiomatic to many of its opponents that globalization undermines human rights. Thus Figure II below investigates models of a negative relationship between globalization and human rights.

FIGURE II (a)

Globalization Undermines Human Rights: The Simple Model

globalization $\Rightarrow$ rightlessness

Globalization, in this model, can have only negative social, political, and economic effects. People are more likely to enjoy their human rights if they live in a locally, rather than globally-controlled environment. To use a phrase coined by J. Oloka-Onyango and Sylvia Tamale, globalization is "survival of the meanest[.]"51 Put another way, says Anthony Giddens, this view of globalization would argue that it results not in a global village but in global pillage. ${ }^{52}$ This is how the Economist accuses the Canadian antiglobalization crusader, Naomi Klein, of seeing the world. ${ }^{53}$ In this view, globalization is a zero-sum game, which human actors, namely Western capitalists and Western political leaders, have invented for their own benefit. These actors use international organizations such as the World Trade Organization as agencies of "unofficial global government enforcing

51. Joe Oloka-Onyango \& Sylvia Tamale, "The Personal is Political," or Why Women's Rights are Indeed Human Rights: An African Perspective on International Feminism, 17 Hum. Rts. Q. 691, 727 (1995).

52. Giddens, supra note 21 , at 16 . The term "global village" is from Marshall Mcluhan, The Gutenburg Galaxy: The Making of Typographic Man 31 (1962).

53. Face Value, supra note 3 , at 70. 
a corporate agenda" on states and citizens who cannot defend themselves against economic attack. ${ }^{54}$ Thus the "local," the concrete, physical place of human happiness and economic security, must be defended against the ethereal space of uncontrollable global change. ${ }^{55}$

FIGURE II (b)

Globalization Undermines Human Rights: The Simple Model Complicated

globalization $\Rightarrow$ de-development $\Rightarrow$ rightlessness

Opponents of globalization insert de-development rather than wealth as the intervening variable between globalization and human rights. The concept of development includes the idea that growth must be accompanied by human rights, as the United Nations proposed as long ago as 1986 in its Declaration on the Right to Development. This Declaration defines development as "an inalienable human right by virtue of which every human person and all peoples are entitled to participate in, contribute to and enjoy economic, social, cultural and political development, in which all human rights and fundamental freedoms can be fully realized."56 This definition of development implies equitable distribution of wealth, ecologically sound investment (sustainable development), and nonexploitive social relationships, such as co-operative rather than profit-oriented production.

The United Nations definition of development is logically redundant, and moreover is superfluous, diverting attention from the much more powerful and concrete earlier (1966) Covenants on Civil and Political, and Economic, Social and Cultural Rights. Nevertheless, the Declaration serves as a powerful rallying cry for individuals and peoples (including the "South") to oppose the disruptive forces of globalization. Its opponents assume that by its very nature globalization will undermine development, not promote it. In this view, equitable distribution of wealth, sustainable development, and nonexploitive social relationships are irrelevant to the process by which international (especially American) capitalism make profits. Globalization's enemies assume that without their opposition, the social changes and political processes induced by globalization will be such as to further the interests of the already rich and powerful.

54. Bruce Grierson, Kalle Lasn \& James MacKinnon, WTO Seattle 99 (anti-globalization demonstrations), 28 Adbusters 64-66 (Dec. 1999-Feb. 2000). See also Ellen Gould, Canadian Connection in Seattle: WTO '99, 29 Briarpatch 6, 6-10 (2000).

55. See Dirlik, supra note 44.

56. Declaration on the Right to Development, adopted 4 Dec. 1986, G.A. res. 41/128, adopted 4 Dec. 1986, U.N. GAOR, Supp. No. 53, 41 st sess., Annex (1986). 
FIGURE II (c)

Globalization Undermines Human Rights: The Simple Model Further Complicated

globalization $\Rightarrow$ market economies $\Rightarrow$ liberal economic order $\Rightarrow$

class society (rich vs. poor) $\Rightarrow$ rightlessness

Opponents of globalization focus on the detrimental short and mediumterm consequences of the spread of capitalism for many hundreds of millions of people. Although capitalism is the only known mode of production that results in a significant increase in the wealth of a society, such an increase does not in and of itself imply more equitable distribution of resources, nor does it imply that social interactions will be nonexploitive. Usually, but not always, early capitalism implies the opposite. Moreover, the new form of capitalism of the late twentieth-century, focusing on finance capital rather than on industrial investment, seems to have radically increased the level of inequality in the world. In 1999 the United Nations reported that the richest 20 percent of the world controlled 86 percent of the world's gross domestic product, while the poorest 20 percent controlled only 1 percent. ${ }^{57}$ In 1988 the income ratio of the world's richest 5 percent to the world's poorest 5 percent was $78: 1$ : by 1993 it had widened to $114: 1 .{ }^{58}$

And it appears that globalization is forcing onto an unwilling world the conditions of early Western European capitalism, ignoring the international human rights laws that now prohibit those conditions. According to Richard Falk, neo-liberal capitalism is characterized by "liberalization, privatization, minimizing economic regulation, rolling back welfare, reducing expenditure on public goods, tightening fiscal discipline, favoring freer flows of capital, strict controls on organized labor, tax reductions, and unrestricted currency repatriation." ${ }^{59}$ Falk's description fits the picture of the conditions often imposed by the International Monetary Fund on borrowing countries. ${ }^{60}$ In effect, the IMF imposes these conditions without regard for the immorality implicit in forcing non-Western, mostly nonwhite human beings of the late twentieth and early twenty-first centuries to live in conditions known to have been intolerable in the white West two centuries ago. Moreover, gross material inequalities are more likely to impede than to facilitate change in the direction of a democratic and rights-protective

57. United Nations Development Program, Human Development Report 1999 (1999), cited in Jeff Madrick, The Charms of Property, 48 N.Y. Rev. Bоoкs, 31 May 2001, at 39.

58. K.S. Jomo, Mondialisation, Inegalite des Revenus et Tendances de la Politique Sociale, 22 Le bulletin de l'institut de reCherche des nations unies pour le deVeloppement social 5, 5 (2000).

59. FALK, supra note 20 , at 2 .

60. Stiglitz, supra note 6 at $43-52$. 
society. Balanced economic development, accompanied by an attempt to provide basic economic rights, is more likely to result in simultaneous increase in protection of civil and political rights. ${ }^{61}$

Globalization's opponents do tend to exaggerate its detrimental consequences, however. The spread of capitalism results in uneven social change. Many millions of individuals benefit from new job opportunities, new markets, and a new capacity for mobility, whether from the village to the town or from China to the United States. Giddens claims that between 1980 and 1994 "[t] he global labor force grew by some 630 million between 1980 and 1994, far outstripping population growth." ${ }^{62}$ The eventual outcome of globalization even for the poorest society is not necessarily negative, even in the short term. Social activists who oppose or try to stem globalization fight a rear-guard action that if successful could deprive hundreds of millions of poor people of new and profitable economic opportunities. But these opportunities would not necessarily mean that these poorer societies would become more rights-protective.

How then, does a society change from a global system of capitalism that results in deep inequalities and social exploitation, to a system that promotes relatively equal social relationships and relatively equal distribution of wealth? The first answer to this question is that such a change is not inevitable. If it does occur, it will occur because of multiple changes-some economic, some political or legal, some social-that may result from globalization. Below, I suggest a model of such social change, adopting as my starting point the same starting point as both Meyer and Smith; namely, multinational investment.

\section{COMPLEX MODELS OF THE RELATIONSHIP BETWEEN GLOBALIZATION AND HUMAN RIGHTS}

In the models presented below, I follow Meyer and Smith in using investment by transnational corporations [TNCs] as a proxy for economic globalization. I first propose a "positive" model of how globalization might result in economic development and better protection of both civil/political and economic rights. I then follow this with a "negative" model of how globalization might result in de-development, and lesser protection of human rights. Adopting the proxy of TNC investment generates complex models, and there is no suggestion in either of the two models below of any

61. Zehra F. Arat, Democracy and Human Rights in Developing Countries 103 (1991).

62. Anthony Giddens, The Third Way and its Critics 125 (2000). Giddens cites no source for these figures, however. 
inevitable relationships. Nor are these models complete pictures. But they do show, at the least, how very complex and contingent is the transition to a rights-protective society.

\section{A. The Optimistic Model}

Figure III (a) starts with one, and only one, change introduced into a society: namely, transnational investment. It assumes a society that is not democratic and does not respect human rights, but that does permit foreign investment. Into such a society, transnational investment impels some changes. These changes are along the lines proposed by the "engine of development" school analyzed by Meyer. ${ }^{63}$ This school asserts that TNCs create jobs, provide employee benefits, and help create a middle class. However, my analysis assumes that these changes are neither linear nor inevitable. All rights, and most especially the socioeconomic rights represented by employee benefits, depend upon social movements and political action. Whatever a theoretical model might suggest about the positive effect of globalization on economic rights, only concrete social action will bring about these benefits. Nevertheless, it is worth constructing a theoretical model of how this might occur.

On the economic front, the most obvious change in a society newly encountering transnational investment is the provision of new employment opportunities. A small and growing group of people now works in the modern, industrial sector. Some of these people will pay taxes to the government, as will the transnational corporation itself (unless it is allowed a complete tax holiday in perpetuity.) Increased national revenue appears to be associated with improvement in human rights. ${ }^{64}$ One can posit a number of reasons why this might be so. Increased national revenue results in a small increment in governmental capacity: with more tax revenue, the government can pay its civil servants more regularly. Such pay gives civil servants an incentive to stay in their offices and abide by bureaucratic rules of fairness and impartiality, rather than wander off to eke out a living in the informal sector, or ask for bribes every time they encounter a citizen with a request. New economic opportunities will also lessen the likelihood that moves toward political democracy will be resisted. Holders of both political and bureaucratic office will be less frightened by the possibility of losing that office if they can assume that they can maintain their standard of living

63. Meyer, Human Rights and MNCs, supra note 24, at 376-77.

64. See Kathleen Pritchard, Human Rights and Development: Theory and Data, in HumAN Rights and Development: International Views 329 (David P. Forsythe ed., 1989). 
FIGURE III (a)

The Second Great Transformation: An Optimistic Model

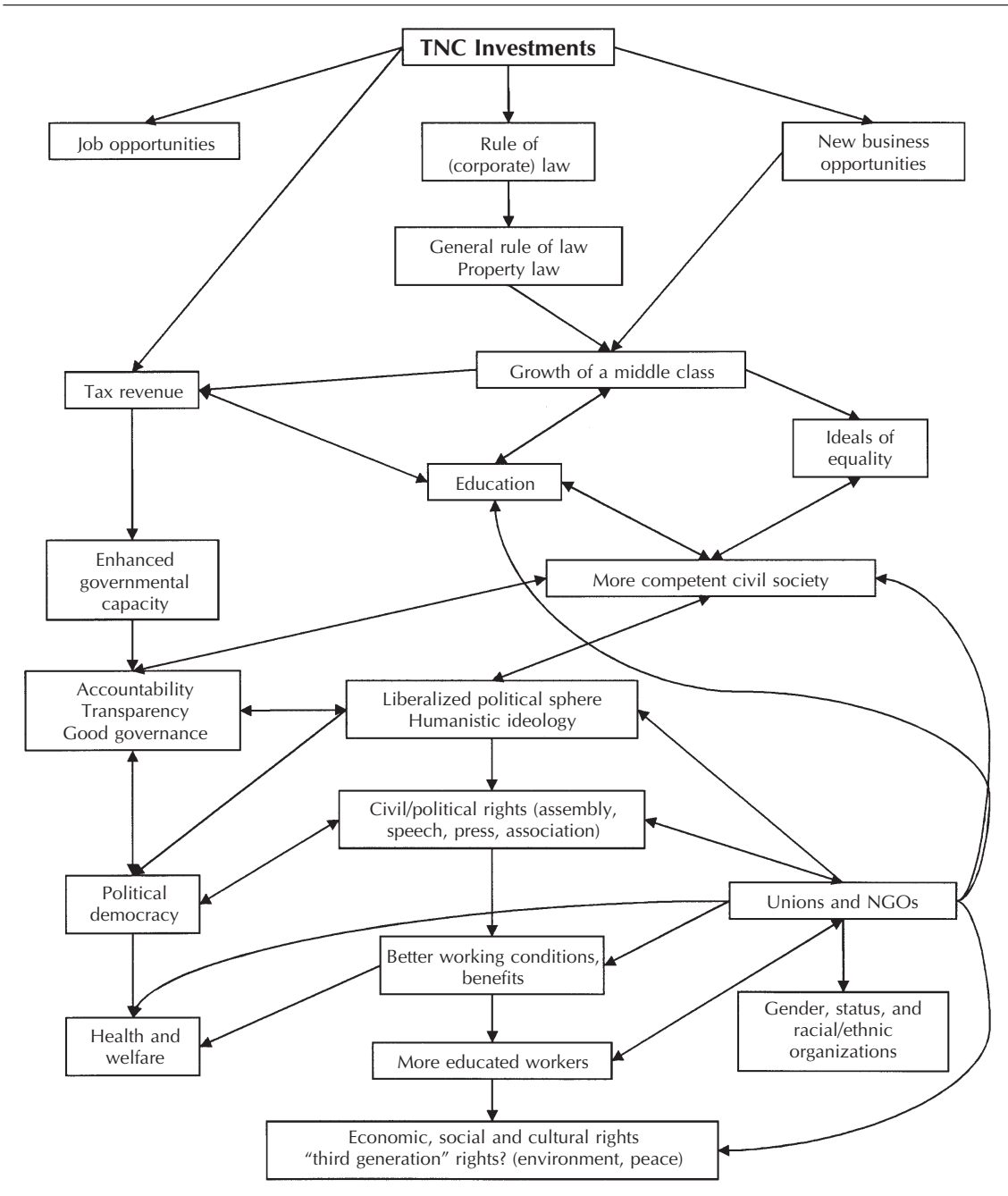

in the private sector. One of the chief causes of political corruption among high-level office-holders, the fact that there are few economic opportunities in the capitalist, legal, and professional sectors to serve as alternate sources of income, will be reduced.

TNC investment will also contribute to the establishment of the rule of law. Investors want predictable laws and competent judicial systems to 
enforce their contracts and their property rights. They do not want governments that renege on their contracts, as China is wont to do, or that are too weak to enforce property laws, as was the case in early postCommunist Russia. The rule of law also provides the opportunity to legally own property, and to have one's property protected by the state. The Peruvian economist Hernando de Soto has argued that one of the biggest stumbling blocks to development in Latin America, Asia, and Africa today is that the poor are not legal owners of their houses, land, and minienterprises. Without legal title, they are at the mercy of corrupt bureaucrats who demand bribes not to evict them from their homes and businesses. Further, without evidence of legally-enforced property, they have no collateral to offer banks for loans. And they cannot enjoy economies of scale, because they often have to disperse their enterprises among many different locations to prevent seizure of their illegal assets. ${ }^{65}$

The spread of property law will assist in the regulation of citizens' myriad private interests. Some of these citizens will be members of the new middle or entrepreneurial class. TNC investment will result in more local business opportunities, either directly in relationship with the TNCs by, for example, supplying locally-made inputs, or indirectly by providing goods and services for workers who have established new communities in the areas of TNC investment. This new middle class will want its own property protected and its contracts enforced.

The new middle class may emerge from the ranks of those who are already educated, as have Chinese entrepreneurs from a socialist society that stressed education. ${ }^{66}$ But this class will also want even more education. It will want its sons, and even its daughters, to be educated so that they can join their parents in business and later manage the property they inherit. It may also want a more educated population in general, so that it can employ individuals with the skills it needs. Here, the TNC may eventually join in a demand for more education, or provide its own educational system, if it discovers it needs a more literate or numerate labor force.

As the new middle class becomes more aware of its own interests, it will become less willing to live under the rule of traditional elders, communist bureaucracies, or personalist dictators. It will establish the rudiments of a civil society, organizing to protect its own interests. This civil society will in turn feed back into the educational system, asking that new ideas of the proper relationship of citizen to ruler be promulgated. It will

\footnotetext{
65. Hernando de Soto, The Mystery of Capital, Twenty-First Morgenthau Memorial Lecture on Ethics and Foreign policy, New York: Carnegie Council on Ethics and World Affairs, available at www.carnegiecouncil.org/media/845_inprint9.pdf (2002). See also Madrick, supra note 57.
}

66. SEN, supra note 2 , at 42 . 
promote ideals of social equality, so as to enhance its own chances of advancement, regardless of the former or present social statuses of its members. It will also enhance governmental capacity, demanding fairness and efficiency, and displaying some willingness to pay taxes in order to obtain them. A more secure bureaucracy will be more willing to listen to the concerns of its citizenry and to respond to them. As it does so, it will learn that it is possible to make changes in policy, even to disburse more funds, without losing control of the state. It will be easier to adhere to the principles of accountability and transparency, key aspects of good governance, in state institutions that are properly funded and in which bureaucrats are well-trained and adequately paid.

An emergent civil society will also begin to demand a more liberalized political sphere. Citizens will start to make their interests known, and will expect their government to take these interests into account. Citizens will want the rule of law to cover areas of life beyond property and contract: they will demand regularity, fairness, and predictability in other spheres of life. A government less reliant than previously on corruption, and more used to bureaucratic procedure, will be more willing to entertain the possibility of liberalizing, gradually opening up to freedoms of speech, press, and association that permit citizens to articulate their wishes.

A more humanistic ideology develops along with—and in part as a cause of-the more liberalized political sphere. As the market spreads and impersonal market relations become more common, commerce begins to take precedence over prejudice. Strangers become individuals with whom transactions are made, rather than bearers of particular identities. A universal moral sense develops. Indeed, Gary Madison goes so far as to argue that the market breeds civility: all parties must communicate with each other in a tolerant fashion, and all must be willing to compromise if exchanges are to take place. The economic agora contributes to the political agora, and market trust helps to build the social trust necessary for a functioning political democracy. ${ }^{67}$ Furthermore, as market relations and contract law impose on individuals a culture of promises, they begin to think of their obligations to distant others in these terms. ${ }^{68}$ Old status distinctions are eroded, and political relations develop among individuals of radically different statuses, as, indeed, occurred in a much earlier period of globalization in the eighteenth century, as Europe began to expand its relations with the entire world. ${ }^{69}$

67. G.B. Madison, The Political Economy of Civil Society and Human Rights 153 (1998).

68. Thomas L. Haskell, Capitalism and the Origins of the Humanitarian Sensibility, Part 2, 90 American Historical Rev. 547, 551 (1985).

69. Emma Rothschild, Globalization and the Return of History, 115 Forelgn Policy 106, 112 (1999). 
The entrenchment of economic rights for ordinary people will require a different and expanded set of social actors, especially members of the working class. People working in the modern, industrialized sector will soon start to make demands. They will want independent trade unions to organize and act as their bargaining agents. As they attain small incremental improvements in working conditions, so they will be emboldened to ask for more rights, such as better access to education. They will also learn how to take part in large, bureaucratized organizations and how to lobby and bargain. As they become more educated and experienced, they will enter other spheres of civil society, generalizing the idea that social welfare should be available to all citizens, whatever their particular status as entrepreneurs or workers. Improvements in education, health, and welfare in turn will spiral backward, affecting the capacity of citizens to take part in a political democracy. Both workers and members of the middle class, now living under the rudiments of the rule of law and the rudiments of political democracy, will absorb the idea that with rights, they are legally equal citizens of their country. This idea will spread to groups that hitherto might have been unsure whether they were equal to others, such as women, persons occupying lower castes or statuses, or ethnic, religious, or racial minorities. They in turn will form their own civic associations and learn the same lobbying and bargaining techniques as other groups in civil society.

The above is not so much a prediction as a rough description of what happened in Western Europe and in North America during and after the period of the first Great Transformation. The introduction of capitalism resulted in the development of social classes capable of articulating their needs. These social classes used their civil and political rights to articulate demands for economic rights. Following the example of the labor movement, status-based movements also emerged: in the US, the AfricanAmerican movement for civil rights and the women's and gay and lesbian movements for equality rights. Both these movements also resulted in enhanced access to economic rights, although severe inequalities still exist between whites and blacks, and between men and women, just as there is still severe income and wealth inequality among the population in general in developed capitalist Western states.

None of the social changes discussed above was inevitable, however. Nor did these social changes occur in the West in a linear fashion. They spiraled back upon themselves again and again. Enhanced governmental capacity, for example, fed into education, which fed into employment, which fed into taxes, which fed into enhanced governmental capacity. Even a spiral does not capture their interrelationships: perhaps several overlapping Mobius strips would be the best visual analogy.

One piece of good news, however, is that almost all countries of the world now accept capitalism. Rueschmeyer, Stephens, and Stephens have 
shown the connection between capitalism and democracy: capitalism is a necessary, though not sufficient, prerequisite for democracy. ${ }^{70}$ Both quantitative and qualitative studies finding a correlation between capitalism and democracy also show that an intervening variable is necessary to effect such a correlation. That intervening variable is class action and organization. In a review of many studies of the relationship between economic development and human rights, Landman also finds that "economic development [usually capitalist] does not enhance directly political or civil rights," but that "social mobilization has a direct relationship with the expansion and contraction of political and civil rights."71

Rueschemeyer, Stephens, and Stephens' analysis confirms Sen's assertion that development depends on human agency: the "achievement of development is thoroughly dependent on the free agency of people." 72 Participatory freedoms are particularly important, says Sen. "Political freedoms (in the form of free speech and elections) help to promote economic security. Social opportunities (in the form of education and health facilities) facilitate economic participation. Economic facilities (in the form of opportunities for participation in trade and production) can help to generate personal abundance as well as public resources for social facilities. Freedoms of different kinds can strengthen one another."173

But the class action and human agency to which Rueschemeyer, Stephens and Stephens refer is not purely voluntarist: it arises only if the structural conditions are appropriate. Democracy, Rueschemeyer, Stephens, and Stephens assert, is "above all a matter of power" ${ }^{74}$ it is necessary for the subordinated classes to wrest democracy from the powerful. Rueschemeyer, Stephens, and Stephens set themselves the task of determining how, and under what structural conditions, social movements for democracy arose. They referred to the many complex sequences-rooted in the actual historical experiences of various countries-that resulted in subordinate

70. Dietrich Rueschemeyer, Evelyne Huber Stephens \& John D. Stephens, Capitalist Development and Democracy 7 (1992).

71. Todd Landman, Comparative Politics and Human Rights, 24 Hum. Rts. Q. 918, 920 (2002).

72. SEN, supra note 2 , at 4 .

73. Id. at 11. The account by Sen, an economist, of the relationship among different kinds of freedoms confirms the account by Henry Shue, a philosopher, of the relationship among different kinds of rights and the need for security (freedom of the person) to supplement subsistence. See Henry Shue, Basic Rights: Subsistence, Affluence and U.S. Foreign Policy (1980). Sen's account also confirms the account of the present author, a political sociologist, of the need for civil and political rights to buttress economic rights. See also Rhoda Howard, The Full-Belly Thesis: Should Economic Rights Take Precedence over Civil and Political Rights? Evidence from Sub-Saharan Africa, 5 Hum. Rts. Q. 467 (1983).

74. Rueschemeyer, Stephens \& Stephens, supra note 70, at 5. 
social classes' developing the capacity to organize. Class action is made possible by transformations in social organization, especially by improvements in education and communication, and by urbanization and the concentration of population. This results in the emergence of civil society as a counterweight to state power.

Not only is capitalism a necessary prerequisite for democracy: Freeman argues that it is also "the only economic system . . . so far . . . found to be compatible with the relatively effective protection of human rights." ${ }^{175}$ Negative evidence to support the connections among capitalism, democracy, and human rights is the abysmal state of human rights in countries that still attempt to organize their economies on bases other than capitalism. Myanmar and North Korea come to mind, but so also does Cuba, which, without the support from Russia that it received from the Soviet Union, has been spiraling downward since 1990. Capitalism does not inevitably result in democracy - much less human rights-as some of the ideologicallyminded promoters of capitalism seem to believe. But without capitalism, democracy appears to be impossible, and without democracy, human rights cannot be protected. Far more than an economic system, capitalism relies on certain presumptions about the rule of law, and capitalism creates modern citizens-both bourgeois and worker-who in the medium to long term demand human rights.

Once again, however, these are not inevitable relationships. Rueschemeyer, Stephens, and Stephens make clear that while there can be no democracy without capitalism, there can certainly be capitalism without democracy. ${ }^{76}$ There can be alliances between "old" and "new" elite classes, as in the alliance between the old landlord class and the new bourgeois class in much of Latin America until the 1990s. That alliance permitted industrialization while blocking the peasants and the urban proletariat from deriving any benefits from the new system of wealth-creation. ${ }^{77}$ Moreover, a state elite can command resources such as decision-making power over investment and tax conditions that make it worthwhile for the international capitalist class to ally itself with that elite, blocking any changes that the lower classes might try to demand. Finally, the military can intervene in the process of capitalist development.

This kind of blockage is even more a prospect in the early 21 st century. The new capitalism of the globalization era is not an exact replica of the

75. Freeman, supra note 35 , at 44 .

76. See Rueschemeyer, Stephens \& Stephens, supra note 70, at 7.

77. For the classic work on this type of class alliance in Latin America, see generally ANDRE Gunder Frank, Capitalism and Underdevelopment in Latin America: Historical Studies of Chile AND BRAZIL (1967). 
type of capitalism that Rueschemeyer, Stephens, and Stephens discuss. ${ }^{78}$ In Russia, for example, a "shock treatment" transition to capitalism was prescribed by American consultants and international financial institutions before sufficient institutional capacity and respect for the rule of law had been developed. This resulted in massive corruption, transformation of the former party-bureaucratic apparat into a speculative property-holding elite, and deep de-development, as demonstrated by Russia's steep decline in population during the $1990 s .{ }^{79}$ We cannot be sure that the happy model presented above of the West's Great Transformation I will be an accurate representation of the Great Transformation II, the spread of global capitalism into the farthest reaches of what were once isolated-and sometimes insulated-communist or peasant societies. Thus, it is necessary to also consider a pessimistic model of the present transformation.

\section{B. The Pessimistic Model}

What happened in the past may not happen in the future. Globalization of capitalism may not result in globalization of democracy and civil/political rights, much less globalization of development and economic rights. Decisions by international organizations that are imposed from above and that restrict the political dynamic that might otherwise occur between a state's government and citizens' movements, can reduce the likelihood that human rights - either civil and political, or economic, social, and culturalwill be attained. Human actions and human decisions will affect any transformation that occurs in the less wealthy parts of the world, whether the still underdeveloped sections of the former "Third World," notably subSaharan Africa, or the "new Europe" (and "new Asia"), those states carved out from the former Soviet Empire.

A key difference between the earlier development in Western Europe of capitalist, democratic, and eventually rights-protective societies, and development occurring in the twenty-first century, is the role of global financial institutions in managing investments. Joseph Stiglitz is extremely critical of International Monetary Fund (IMF) policies regarding investments. ${ }^{80} \mathrm{He}$ is especially critical of the way the IMF encourages "hot money" investments all over the world, without regard to national governments' economic goals. ${ }^{81}$ Hot money flows into and out of a developing country at great

78. See Rueschemeyer, Stephens \& Stephens, supra note 70.

79. Stiglitz, supra note 6 , at 133-65.

80. Id. at 64-67.

81. Id. at 93 . 
speed and can destabilize an economy without providing any economic or human rights benefits. Such hot money amounted in the late 1990s to $\$ 1.5$ trillion per day ${ }^{82}$ Stiglitz has explained not only how this policy contributed to the South-East Asian economic melt-down of 1997, but also how it has permanently reduced national income in that region. Without in any way claiming a knowledge of economics sufficient to verify Stiglitz's argument, I attempt below to schematize his chapter on the Asian crisis and to extrapolate from it to a more general model of how a society that is both growing economically and becoming more politically open can regress. ${ }^{83}$ This is a short-to-medium term picture, not a long-term prognosis; indeed, by 2002 the Asian financial crisis was "receding into the past." ${ }^{84}$ Nevertheless, it serves to show that the optimistic picture presented above, based upon a retrospective reading of how Western Europe and North America developed, is not inevitable. It also serves to show the extreme importance of democratic opposition to the processes of globalization and the necessity for the IMF and the World Bank to develop within themselves the policies of democratic decision-making and public accountability and transparency that they constantly urge on states.

In the pessimistic model of the Great Transformation II, hot money flows into a country as a result of IMF pressure to reduce controls on capital mobility. Hot money looks for quick earnings opportunities on the financial market, not for longer-term earnings requiring investment in infrastructure or manufacturing. There is then, for some reason, an economic crisis, and the hot money flees the country as quickly as it entered. Without capital, businesses cannot pay their debts, and many of them fail; this causes job loss. The local middle class is devastated. There are fewer jobs, either within the foreign investment sector or within the local sector of businesses and professions geared to servicing foreign-owned businesses and the foreigners themselves. Moreover, the middle class's savings are reduced as disinvestment results in lower valuations on locally-owned investments.

As a result of hot money capital flight, government's tax revenue declines, and with it overall government capacity. Governments react by disinvesting in the civil service, thus causing further job loss. Governments also disinvest in social services, especially in education and health. With less investment in education and health, the quality of human capital

82. Held \& McGrew, supra note 17 , at 493.

83. Stiglitz, supra note 6, 89-132. For reviews of Stiglitz, see Purdy, supra note 19; see also Benjamin M. Friedman, Globalization: Stiglitz's Case, 49 N.Y. Rev. Books, 15 Aug. 2002, at 48-50, 52-53.

84. Friedman, supra note 83 , at 52 . 
FIGURE III (b)

The Second Great Transformation: An Pessimistic Model

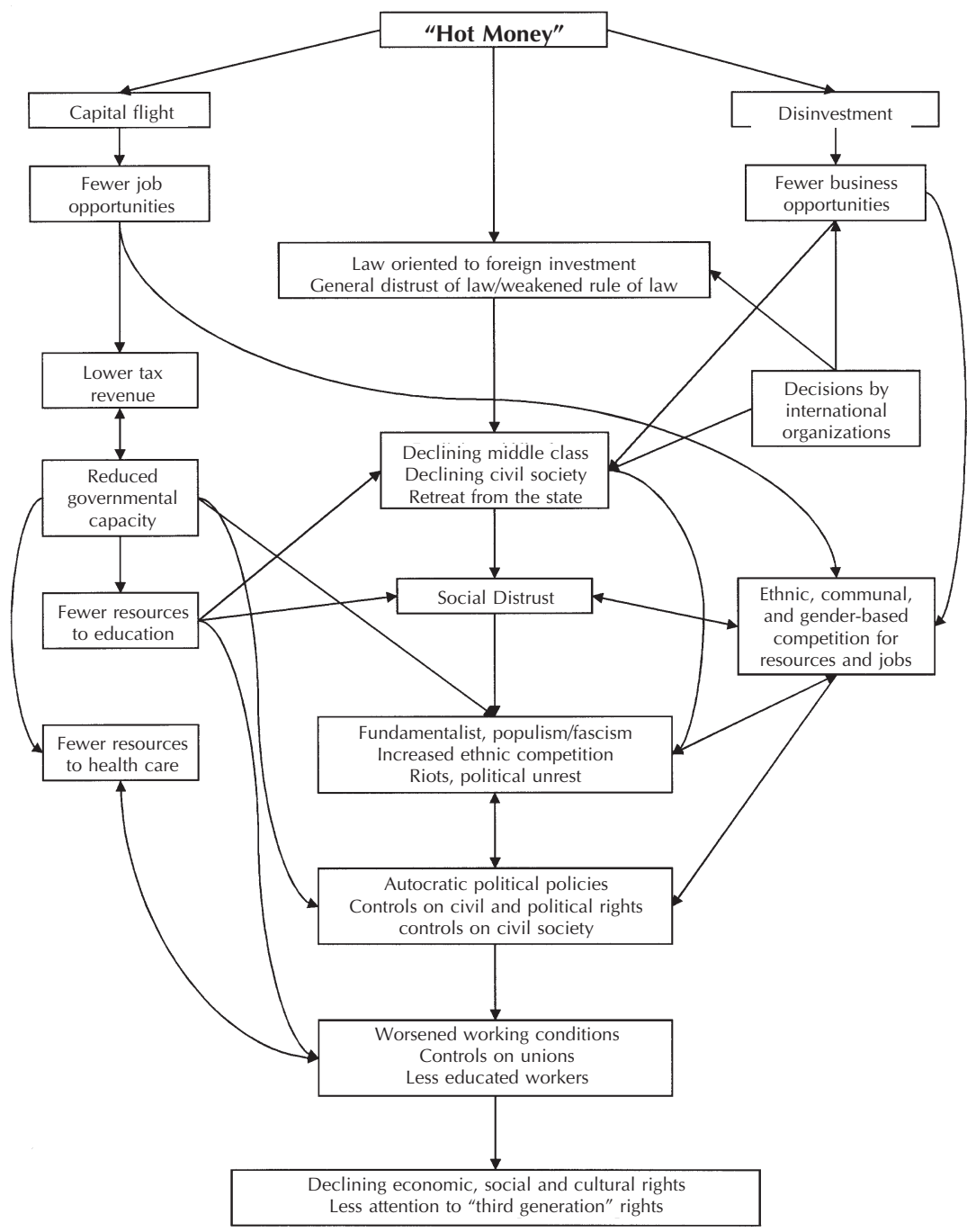


declines, thereby rendering the country less attractive to future investors who might be looking for workers. ${ }^{85}$

Whatever democratization and development of civil society might have previously occurred is also now subject to threat. Society begins to distrust the rule of law, as it becomes obvious that the law has been used to protect the interests of the hot money investors. Distrust in the rule of law generates distrust in government as an institution capable either of ruling or reforming a disintegrating economy, thus communities and individuals retreat from the state. Distrust in law and government expands into a generalized social distrust: far from civilizing social relations, the market separates individuals from each other and from society. Ethnic and communal groups start to compete for jobs, business opportunities, and government hand-outs, and men try to force women back into the home, away from the economic opportunities that have helped women emancipate themselves from patriarchal control. There are food riots and other political manifestations of extreme social unrest. ${ }^{86}$ Fundamentalist political parties, or parties advocating populist/fascist solutions to political crisis, quickly arise, recruiting especially from among unemployable men.

The result of such economic and social crises is often a reversion from democracy to autocratic political policies. As they attempt simultaneously to meet outside economic demands to pay their debts, and to restore civic order, governments impose controls on civil and political rights and on civil society. Attempting to attract international hot money and capital back to the country, they offer a weakened labor force, imposing controls on trade unions. Less educated than previously and less able to exercise their basic civil and political rights, workers are less capable of pressuring either governments or employers for their economic rights, which consequently decline. "Third generation" rights such as the right to development and the right to a clean environment also suffer without active labor movements and civil society organization to pay attention to them.

Stiglitz's description of the meltdown in Asia refers to the very short period of 1997-1999. ${ }^{87}$ The phenomena he describes are the kinds of short and medium-term problems that preoccupy the anti-globalization forces. These phenomena reinforce the point made by Rueschmeyer, Stephens, and Stephens and others, that class action and organization are necessary

\footnotetext{
85. Sen stresses the importance of spending on health and education, in order to develop the human capacity of a nation. See generally $S_{E N}$, supra note 2.

86. Stiglitz, supra note 6, at 119-20, discusses how unwilling the IMF has been to realize that "quick fix" economic policies requiring that governments remove food subsidies will result in riots and further political destabilization.

87. Id. at $89-132$.
} 
connections between capitalism and democracy. ${ }^{88}$ Class action and organization are also necessary to connect capitalism, democracy, and human rights. As the world globalizes, no positive transformation of the human rights situation of ordinary people will occur without a social movement for those rights. This is so even when all economic indicators are positive, and when the rule of law and democratic rule seem "naturally" to evolve. It is even more so when economic indicators are negative, and when the rule of law and democratic politics disappear.

\section{HUMAN RIGHTS AND GLOBALIZATION}

Above, I have discussed human rights only as dependent consequences of globalization. But the principles, laws, and practice of human rights are also independent variables, affecting both elite implementation of globalization and social action in favor of, or against, it. A major difference between the first and second Great Transformations is the existence the second time around of the international human rights regime, and the international human rights social movement.

\section{A. Western Capitalist Evolution and the Absence of Human Rights Law}

The happy predictions made above in Figure III (a), schematizing the optimistic model of the Great Transformation II, rely on similarities to the social evolution of Western Europe and North America. None of this, however, suggests an easy or inevitable transition in the "Rest" of the world from poverty-stricken peasant societies to wealthy industrial societies. Formerly colonized countries in what used to be called the Third World do not have access to one of the most important advantages the West had during its own period of capitalist growth. That advantage was human rights lawlessness. Neither states nor entrepreneurs had to think about the rights of their own citizens or workers, or the rights of those inhabiting the worlds they conquered.

During the West's period of growth, there was no international law to prevent the purchase or theft of people. Thus, the West was able to profit from slavery, as also were those who sold slaves to Westerners. The enslavement of captured or purchased people was a normal activity of the

88. See generally Rueschemeyer, Stephens \& Stephens, supra note 70. 
pre-capitalist and early capitalist periods. ${ }^{89}$ Almost all societies were divided into social categories, some having more rights, privileges, and prestige than others. Thus slavery was an essential part of the triangular trade between Britain, the West Indies, and the Americas, and one of the bases of some Western prosperity. ${ }^{90}$

Similarly, during the period of Western expansion there was no international law prohibiting colonialism. ${ }^{91}$ Colonial conquest was a "normal" practice inherited from the ancient world. It permitted stronger militaries and navies to take over territories previously not part of the world economy, and permitted the colonists to curtail the economies of the conquered territories as they saw fit. If the King of Belgium wished to cut off Africans' hands to prevent them from selling rubber to his competitors, there was nothing to stop him. ${ }^{92}$ Nascent entrepreneurial classes in the colonies of the various European powers soon learned that economic opportunities were reserved for Europeans alone. As, furthermore, there were no laws prohibiting racial discrimination, European merchants, industrialists and financiers could happily confine their working relationships to others of "their own kind." 93

As there were no laws against slavery or colonialism, so also there were no laws against massive population transfers. During the period of Western expansion, citizens - if they could be called that-in the Western world had few rights. Their governments could deport them to the colonies if they disobeyed the myriad laws that regulated their behavior. Their governments could also deprive them of the lands they traditionally owned, as in the conversion of common lands to private property in Scotland and England. ${ }^{94}$ Even famine was a privilege of the state. The English government deprived Irish peasants of their means of sustenance during the famine of the 1840s, "killing a higher proportion of the population than any other famine anywhere in recorded history." 95

89. Joseph E. Inikori, The Struggle against the Trans-Atlantic Slave Trade: The Role of the State, paper presented at Fighting Back: African Strategies against the Slave Trade, Rutgers University, New Brunswick, N.J., 16-17 Feb. 2001.

90. For a classic (although controversial) statement of this relationship, see ErIC WILlaAms, Capitalism \& Slavery (Capricorn Books, 1966).

91. Max du Plessis, Historical Injustice and International Law; An Exploratory Discussion of Reparation for Slavery, 25 Hum. RTs. Q. 624, 657 (2003).

92. Adam Hochschild, King Leopold's Ghost: A Story of Greed, Terror and Heroism in Colonial Africa 165 (1998). Hochschild draws heavily on E.D. Morel, The Black Man's Burden: The White Man in Africa from the Fifteenth Century to World War I 109-26 (Monthly Review Press, 1969).

93. See generally Max du Plessis, supra note 91.

94. As brilliantly memorialized in KarL MARX, CAPITAL, Vol. I, 717-33.

95. SEN, supra note 2, at 170 . 
Finally, in the early modern capitalist world, no international law prohibited genocide and ethnic cleansing. Although there were some protests-from Catholic and other missionaries against the treatment of aboriginal populations in the Americas, for example-by and large colonists could do as they pleased to wipe out the "primitive" populations occupying territories that they sought. ${ }^{96}$ At a time when only a very small percentage of the population of Western states enjoyed anything resembling human rights, few worried about the human rights of the inhabitants of the colonies. Germany committed genocide in South-West Africa with an impunity broken only by a British inquiry after the former country's defeat in World War 1.97

Human rights lawlessness, then, gave industrializing Western powers several privileges that are not enjoyed by industrializing regimes in the early twenty-first century. These privileges were the use of slavery, colonialism, expulsions, famine, and genocide as tools to economic growth. States and ruling classes often prospered under these conditions of lawlessness, although ordinary people often did not. None of these advantages of human rights lawlessness, however, assured the prosperity of the Western world, absent the sorts of social changes diagramed in Figure III. Not all colonial powers became equally prosperous, as the example of Catholic Spain illustrates.$^{98}$ Nor did all slave-trading economies become equally wealthy, as Portugal demonstrates. Internal changes in habits, laws, entrepreneurial activities, and relations among social groups were also important determinants of capitalist growth.

Therefore, in a global world now characterized by human rights constraints, less-developed countries will be at some disadvantage compared to their Western predecessors, in engaging in the capitalist path. On the other hand, as compared to citizens of the West until well into the twentieth century, citizens of these less-developed countries are at an advantage in demanding their rights.

96. See Ward Churchill, A Little Matter of Genocide: Holocaust and Denial in the Americas, 1492 to the Present (1998).

97. Horst Dreschler, The Herero Uprising, excerpted in Frank Chalk \& Kurt Jonassohn, The History and Sociology of Genocide: Analyses and Case Studies 231-48 (1990); see also Jon Bridgman \& Leslie J. Worley, Genocide of the Hereros, in Century of Genocide: Eyewitness Accounts and Critical Views 3, 3-40 (Samuel Totten, William S. Parsons \& Israel W. Charny eds., 1997).

98. Immanuel Wallerstein, The Modern World-System II: Mercantilism and the Consolidation of the EUROPEAN World-ECONOMY, 1600-1750 179-85 (1980). 


\section{FIGURE IV}

Social Action and Human Rights

Social Action and Ideological Change

Economic Globalization

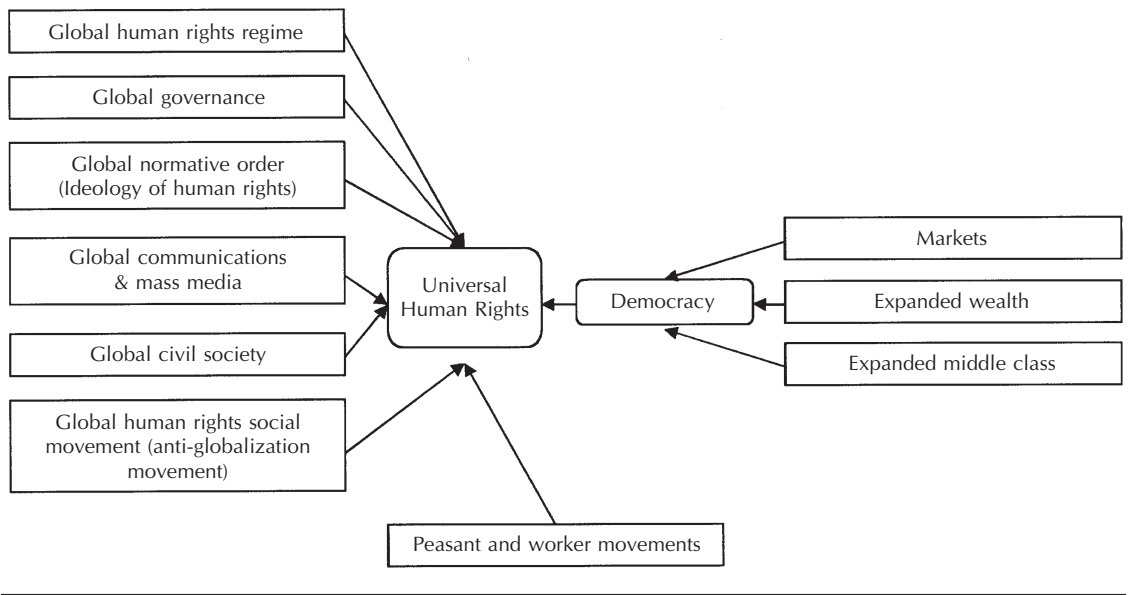

\section{B. Non-Western Capitalism and the Presence of Human Rights}

Figure IV shows the many aspects of the global order that now affect the spread of human rights. To begin with, the entire world is now constrained - to a greater or lesser extent-by the international human rights regime, a set of norms and laws which most countries have formally said they respect. ${ }^{99}$ These norms and laws mean newly industrializing countries are not supposed to engage in the same wealth-creating activities as their Western predecessors: they are not supposed to engage in slavery, colonialism, genocide, massive population transfers, or deportations of citizens they do not want. Nor are they supposed to ignore the basic economic needs of those individuals who by law are their citizens. Thus it is difficult for them to engage in Marx's primitive capitalist accumulation-that stage of looting and plunder that Marx argued constituted the basis for the next, more productive stage of capitalist growth. ${ }^{100}$

But what is lost as an advantage of states is gained as an advantage of citizens. Citizens in places now being reached by globalization do not need

99. For summaries of how this regime works, see Jack Donnelly, International Human Rights 51-85 (2d ed., 1998); see also David Forsythe, Human Rights in International Relations $3-$ 138 (2000); see also Geoffrey Robertson, Crimes against Humanity: The Struggle for Global JUSTICE 1-123 (1999).

100. MarX, Capital, supra note 94 , at 713-72. 
to wait 150 or 200 years before attaining their rights. Globalization speeds up their access to the very idea of rights.

Globalization accomplishes this first of all through the evolution of a global communications network. With the Internet and email, it is easy for citizens of all nations of the world to acquire information and to communicate with each other instantaneously. Citizens are no longer mere consumers of information: they are generators of knowledge and debaters about social issues. Human rights abuses are now subject to "cosmopolitan publicity" in a transnational public sphere. ${ }^{101}$ Civil society actors have immediate access to knowledge and immediate capacity to criticize public policy decisions by local, state, and international agencies. This contributes to that "communicative interaction" that Habermas says is so important for true democracy. ${ }^{102}$

Beetham notes, further, the importance of international civil society to the promotion of human rights. ${ }^{103}$ The civil society actors who now populate global public space possess an "ability to forge links with popular struggles at the most local level anywhere in the world."104 Although themselves a new kind of elite, they link the developed and nondeveloped parts of the globe, the democracies with authoritarian states, in a discussion of human rights that only the most draconian restrictions on access to the international communicative media can control.

This communications network in turn enables the formation of global social movements in favor of human rights. ${ }^{105}$ Human rights social movements have benefitted from the ease of travel and communications of the last thirty years. People living in remote parts of the globe can form alliances with civil society actors in the developed world, and persuade the mass media to take up their case, as did Ogoni activists in South-east Nigeria in the 1990s. This is not, of course, a perfect system. For every successful international campaign there are others that are not successful; success often depends on good organization and even on particular incidents, such as the tragic hanging of the Ogoni leader, Ken Saro-Wiwa, in 1995. ${ }^{106}$

101. James Bohman, International Regimes and Democratic Governance: Political Equality and Influence in Global Institutions, 75 INT'L AfF. 499, 506 (1999).

102. Jurgen Habermas, Struggles for Recognition in the Democratic Constitutional State, in Multiculturalism: Examining the Politics of Recognition 107 (Amy Gutmann ed., 1994).

103. See Beetham, supra note 43 , at 58-70.

104. Id. at 68 .

105. See generally Margaret E. Keck \& Kathryn Sikkink, Activists Beyond Borders: Advocacy Networks in International Politics (1998).

106. Clifford Bob, Globalization and the Social Construction of Human Rights Campaigns, in Globalization and Human Rights, supra note 5, at 133, 133-47. On the much-studied Ogoni movement, see also Claude E. Welch, Jr., Protecting Human Rights in Africa: Strategies and Roles of Non-Governmental Organizations 111-16 (1995); Sigrun I. Skogly, Complexities in Human Rights Protection: Actors and Rights Involved in the Ogoni 
Nevertheless, as global communication erodes geographical remoteness, the universal principle of human rights becomes one upon which local actors can base their demands for justice. If the capitalist-owned mass media ignore a particular human right, the technology of global communications nevertheless allows its pursuit through the formation of independent media groups, chat rooms, and websites. ${ }^{107}$

Global consumer campaigns against abusive labor practices such as employment of child labor have been particularly successful. The Rugmark campaign, for example, tells consumers whether rugs they have purchased from Asia are made without child labor, exerting pressure for improved labor standards in producing countries such as Pakistan and Iran. ${ }^{108}$ Retail companies are also susceptible to consumer pressure on human rights grounds, such as in the case of the Swiss grocery chain, Migros. Migros inserted a "social clause" in its contract with Del Monte to ensure that working conditions on Del Monte's pineapple farms in the Philippines were above average. ${ }^{109}$ If, as the shoe company advertises, "On Planet Reebok there are no boundaries," 110 then one of the advantages of globalization is the capacity of civil society actors in newly industrializing societies to learn from civil society actors elsewhere. With regard to the campaign in the 1990s against Nike's labor policies, Smith et al. were correct to note that "in the absence of consumer mobilization . . . human rights violations . . . constitute only minor factors in TNC profit equations ...." ${ }^{\prime 111}$ Equally, Meyer was correct to note the "spotlight phenomenon" of media and NGO pressures on Reebok to stop buying soccer balls from Pakistani subcontractors who used child labor. ${ }^{112}$ The cumulative effect of these campaigns is strong.

There are now voluntary international codes of conduct for transnational corporations, evolving in part from the twenty-year long campaign before the end of apartheid to oblige multinational investors to treat their black

Conflict in Nigeria, 15 Netherlands Q. Hum. Rts. 47, 47-60 (1997); Amos Adeoye Idowu, Human Rights, Environmental Degradation and Oil Multinational Companies in Nigeria: the Ogoniland Episode, 17 Netherlands Q. Hum. Rts. 161, 161-84 (1999).

107. On independent media groups, see William Meyer, Global News Flows: Dependency and Neoimperialism, 22 Comp. Pol. Stud. 243 (1989).

108. Forsythe, supra note 99, at 207; Raul C. Pangalangan, Sweatshops and International Labor Standards: Globalizing Markets, Localizing Norms, in Globalization and Human RIGHTS, supra note 5, at 98, 107.

109. Pangalangan, supra note 108, at 108.

110. Cited in Benjamin Barber, Jihad versus McWorld: How Globalism and Tribalism are Reshaping THE WORLD 24 (1995).

111. Smith et al., supra note 31 , at 211.

112. Meyer, supra note 32, at 224-25, citing Debora L. Spar, The Spotlight and The Bottom Line: How Multinationals Export Human Rights, 77 For. Aff. 7, 8-9 (1998). 
South African workers better. ${ }^{113}$ There is also a movement among international lawyers to bring transnational investors under the constraints of the international human rights regime. ${ }^{114}$ The International Labor Organization has found a new centrality in the elaboration of minimum human rights standards for transnational corporations, even if it does not yet have the authority to impose these standards. ${ }^{115}$ The Organization for Economic Cooperation and Development has also elaborated voluntary guidelines for multinational enterprises, including the right of workers to form trade unions. ${ }^{116}$

Giddens notes that civil society organizations such as the environmentalist group Greenpeace and the anti-poverty organization Oxfam are themselves now global institutions. ${ }^{117}$ The feminist movement is also international: women from all over the world, from the most remote regions and least advantaged social groups, can meet to discuss common problems, as occurred at the Vienna Conference on Human Rights in 1993 and at Beijing in 1995. ${ }^{118}$ These common topics include defense of women workers' rights in countries experiencing rapid transnational investment. Unlike women in the Western world, women in the newly globalizing world do not have to wait until men are able to assert their rights and then follow behind. Assertion of the rights of all social categories, in all social situations, occurs simultaneously in the world of global communications.

The international human rights movement is also assisted by an unprecedented level of global governance. Scholars make frequent reference to states' voluntary abrogation of (some) sovereignty in favor of international treaties and regulations. But global governance is not only a matter of formal institutional development, or proclamation of new treaties and laws. It is also a matter of new space for citizens' movements. Rosenau speaks of international social movements as "well-springs of global governance." 119 This "noneconomic fabric of ties" among citizens world-wide

113. See Mzamo P. Mangaliso, The Corporate Social Challenge for the Multinational Corporation, 11 J. Bus. Eтнісs 491 (1992).

114. Pangalangan, supra note 108, at 98-112. See also Amnestr International (Dutch Section) \& Pax Christi International, Multinational Enterprises and Human Rights: A Report (Utrecht, Nov. 1998).

115. Forsythe, supra note 99, at 202-03.

116. Ron Bean, Comparative Industrial Relations: An Introduction to Cross-National Perspectives 207 (2d. ed., 1994).

117. GidDens, supra note 21 , at xxv.

118. See Martha Alter Chen, Engendering World Conferences: The International Women's Movement and the UN, in NGOs, the UN, \& Global GovernanCe 139, 139-55 (Thomas G. Weiss \& Leon Gordenker eds., 1996); see also Elissavet Stamatopoulou, Women's Rights and the United Nations, in Women's Rights, Human Rights: International Feminist Perspectives 36, 36-48 (Julie Peters \& Andrea Wolper eds., 1995).

119. James N. Rosenau, Governance and Democracy in a Globalizing World, in RE-IMAGINING Political Community: Studies in Cosmopolitan Democracy, supra note 43, at 28, 42. 
acts as an antisystemic force to which formal authorities must pay attention. ${ }^{120}$ Global space is densely populated, and within it there is much pressure for cosmopolitan democracy.

While it is precipitous to argue that national sovereignty has significantly declined as a result of the establishment of international law and the various regimes that limit most states' capacity to act unilaterally in the economic, environmental, or other areas, both the reach and the depth of international law has been significantly extended. The argument that economic growth requires a free hand both for capitalists and governments without regard to political democracy or the rule or law has little credence in the early twenty-first century.

Thus globalization speeds up the processes not only of capitalist expansion, but also of resistance to capitalism. Social action promotes human rights not only in theory, but also in practice.

\section{HUMAN RIGHTS LEAPFROGGING}

In the game of leapfrog, little children line up in a row, then leap over each other's backs, the child at the end starting first. In the human rights world, rights now leap over much larger obstacles. In the contemporary global society, oceans are crossed and centuries ignored as all sectors in the world engage in a giant debate about what human rights are or ought to be, what people from different parts of the world are entitled to, and who or what agencies are expected to respect or implement those rights. Over the Atlantic and Pacific Oceans, the Mediterranean and Black Seas, human rights leap from developed to underdeveloped regions. Over the centuries of the first Great Transformation, human rights leap to the Second Great Transformation. And as in the children's game of leapfrog, the last are often first. Those most deprived demand to go to the head of the line. They demand enjoyment of all the rights to which they are told by international law they are entitled, despite the relative economic underdevelopment and political and legal backwardness of their own societies. Patience is not enjoined upon them: they are not told their time will come.

Despite efforts of political and cultural spokespersons of various kinds to shut down the borders, it is increasingly difficult for those who suffer human rights abuses not to hear the voices of human rights defenders. Global solidarity is an important aspect of globalization: in 2000 there were 16,500 trans-border civil society organizations. ${ }^{121}$ Thus globalization is not

120. Id.

121. Jan Aart Scholte, Globalization: An Introduction 58 (2002). 
merely a phenomenon coming from "above" in the form of transnational organizations and corporations. It is also a phenomenon originating from below, often in the form of "grass-roots globalization," local organizations in the underdeveloped world that can connect via the Internet, email, or jetset NGO conferences with international human rights organizations based in the West. ${ }^{122}$

Thus, human rights leapfrogging simultaneously promotes rights, but is itself an aspect of globalization to which many object. Reflecting the changes that occurred in Polanyi's Britain in the eighteenth and nineteenth centuries, human rights are posited upon the basic civil and political rights that communitarian political systems frequently deny; namely, freedoms of speech, assembly, press, and association. Human rights are also posited upon a zone of personal privacy, in family relations, in economic activities, and in individual decision-making. To some people trying to protect their own societies, religions, and cultures from the homogenizing tendencies of globalization, the global norms that human rights activists propose seem suspiciously like "Western" norms. Some influential individuals in the developing world consider the human rights movement to be propounding a "foreign" global normative system that requires social and cultural, as well as political, legal, and economic change. The charge of cultural imperialism is frequently heard, and the politics of resentment is manipulated to hold back the tide of human rights.

Human rights leapfrogging is one positive aspect of globalization, but it is no guarantee of ultimate global respect for human rights. No social scientist can predict the future, nor do those anxious to protect their academic reputations attempt to do so. The fact that over the course of two centuries the capitalist West gradually became wealthy, relatively free, and democratic does not mean all other societies will inevitably do likewise. And the Western world's many deviations from a steady progress to protection of human rights are well known.

Nevertheless, globalization has spread the idea of human rights world wide. It has speeded up social change. Ideas and rules of human rights leapfrog across oceans and centuries, intersecting with social changes on the ground. Countries such as Taiwan and South Korea have already followed paths to become relatively rights-protective societies, similar to the path outlined above in Figure III (a). They did so in fifty years, not 200. Thus this model is not confined to the West, despite the West's obvious initial advantages in industrializing.

Globalization is, then, a powerful potential tool for promotion of

122. Arjun Appadurai, Grassroots Globalization and the Research Imagination, 12 Puв. Culture 1, 15 (2000). 
human rights worldwide. But whether, in the end, it promotes or hinders human rights is not something that can be determined by quantitative studies of the kind undertaken by Meyer and Smith. Nor can it be determined by adding up the numbers of jobs created and comparing them with the numbers lost. The long-term time frame of the second Great Transformation may well be shortened by the technology of globalization from the 200 years of the first Great Transformation to, perhaps, fifty years. But the final outcome cannot now be predicted. It is no more sensible to pass judgment on globalization as an instrument of social change that it would have been sensible to pass judgment on the Industrial Revolution in 1780 or 1800 . Now, as then, the short-term detrimental consequences are obvious. Now, as then, humanitarians must strive to overcome the harms of dispossession, underemployment, and poverty. But now, as then, we do not know the final outcome. 